\title{
COMMUNITY OF PRACTICE AS A FORM OF VOLUNTARY ACADEMIC COOPERATION
}

\author{
Grażyna Prawelska-Skrzypek* $\odot$ http://orcid.org/0000-0002-5314-1910 \\ Justyna Maciag ** http://orcid.org/0000-0003-2833-4945 \\ Tammi Sinha*** $@$ http://orcid.org/0000-0001-7693-2275 \\ Christina Welch**** $\odot$ http://orcid.org/0000-0003-1208-5948 \\ Nigel Ward*****
}

\begin{abstract}
Background. Contemporary challenges motivate academics to look for forms of activities stimulating creative processes, releasing creativity, and supporting cooperation between universities and their socio-economic environments, including the expansion of knowledge with the active participation of these environments. Such effects are brought about by cooperation within the framework of a community of practice - a traditional form of academics' organizing themselves that is currently being rediscovered.
\end{abstract}

Research aims. A presentation and analysis of examples of informal academic cooperation in Poland and the United Kingdom.

Methodology. A case study has been conducted on the basis of statements made by British and Polish researchers and practitioners involved in communities of practice.

Key findings. The result of the conducted research is the identification of a theoretical basis necessary for understanding various types of voluntary cooperation within an academic community. The research results show that communities of practice are an effective way of working thanks to the stimulation of creative processes, academics' individual development, and advantages gained by institutions. Their key strengths are the absence of formalization and the joy of creation. They constitute a renaissance of the traditional forms of work compatible with academics' styles of living.

Keywords: informal academic cooperation, community of practice

JEL Codes: I23

\footnotetext{
* Jagiellonian University in Cracow. E-mail: grazyna.prawelska-skrzypek@uj.edu.pl

** Jagiellonian University in Cracow. E-mail: justyna.maciag@uj.edu.pl

*** University of Winchester. E-mail: tammi.sinha@winchester.ac.uk

$* * * *$ University of Winchester. E-mail: christina.welch@winchester.ac.uk

***** University of Portsmouth. E-mail: nigel.ward@port.ac.uk
} 


\section{INTRODUCTION}

In the traditional academic culture, knowledge workers were able to enjoy considerable freedom in not only determining their individual fields of research but also organizing their own work and cooperation, conducting research and didactic activities, as well as pursuing careers. The contemporary concepts of the university negate the previous principles and standards applicable to the practice of science. Consequently, what follows is a considerable reduction of the independence of teaching and conducting research, as well as changes in the ways of academic work.

This paper aims to present examples of activities based on various forms of bottom-up organization, self-fulfilment, and self-reflection, as well as their impact on the development of scientific knowledge, the professional development of academics, the shaping and strengthening of academic cultures and academic ethos. In this way the authors want to verify Habermas's opinion as presented by M. Geppert and G. Hollinshead. Pondering over the means of protecting the autonomy of academic research and teaching against political or economic interventions, Habermas referred to the forms of non-instrumentalized communication and cooperation in the Lebenswelt of the academic community (Habermas, 1987; Geppert \& Hollinshead, 2017, p. 138). According to S. Collini, voluntary cooperation and individual autonomy are the most important sources of intellectual activity (Collini, 2012). Such cooperation may adopt various forms and be permanent or incidental, intentional or coincidental.

The paper focuses in particular on examples of informal academic cooperation, including that characteristic of communities of practice. The authors intend to examine whether, and if so to what extent, communities of practice exert a positive influence on the pursuit of objectives by universities and society at large.

The paper outlines the theoretical fundamentals of communities of practice and describes examples of various types of voluntary cooperation within the academic world with emphasis placed on the effects of such cooperation for participating academics. The authors discuss a case of a British university where academics establish networks used as channels between universities and society at large for the purpose of developing skills and knowledge. The key for achieving this purpose and for the spreading of knowledge from universities functioning 
as living laboratories (Evans et al., 2015, p. 2; Graczyk, 2015) is cooperation among researchers and practitioners. The case study has been conducted on the basis of statements made by British and Polish researchers and practitioners involved in communities of practice.

\section{COMMUNITIES OF PRACTICE: FUNDAMENTALS}

Nonaka (1991) reiterates this beautifully:

Creating new knowledge is not simply a matter of processing objective information. Rather, it depends on tapping the tacit and often highly subjective insights, intuitions, and hunches of employees. The means of making use of such knowledge are often soft - taking the form of slogans, metaphors and symbols - but they are indispensable for continuous innovation.

He presents four patterns for creating knowledge:

1. Tacit to tacit - socialization as in person to person - because their knowledge never becomes explicit, it cannot be easily leveraged as a whole.

2. Explicit to explicit - combination, in combining existing pieces of knowledge which does not extend the organisation's existing knowledge base.

3. Tacit to explicit - articulation as in learning and sharing as part of a group.

4. Explicit to tacit - internalization as in new knowledge becomes part of our routines and thinking patterns.

When we have created knowledge we have four strategies for taking it to the next level. Sharing is a way for improving how we do this. However, it may involve challenging social norms and creating communities of practice and other social networks. Leveraging this knowledge involves creating additional revenue streams from this knowledge in terms of new products and services. In the case of universities, such products are new programmes in terms of teaching, research and knowledge exchange. Creating new knowledge comes from creativity, genuine insights and the ability (and opportunity) to recombine existing sets in new ways. We also need time and space for reflection, high levels of trust and mechanisms for ideas to collide. The higher education is unique in that we are partners, collaborators and competitors with each other. Our living laboratories provide us with the opportunity to do this. Competing on the basis of knowledge gives universities and 
other organisations a chance to reposition themselves. Three enablers bring this together, our knowledge processes. This is identification, acquisition, mapping, storing, accessing, distributing, leveraging and using this knowledge. Universities do this through scholarship, knowledge exchange and high quality teaching. Technology enablers involve information systems, cloud computing, document sharing and virtual learning environments. The way the organisation is aligned with this is made explicit through the leadership style embraced by the senior team, the rewards and recognition systems set, governance structures and the approach to openness.

As knowledge is inherent within individuals, the use of informal networks and communities of practice should not be underestimated. So what is a "community of practice"? Herranz et al. (2012) propose that it is:

A group of people who share a set of problems, or a passion for something and wish to deepen their understanding and expertise by interacting on an on-going basis.

Lave and Wenger (1991) and Wenger (1999) presents this perspective:

A set of relations among persons, activity, and world, over time ... A community of practice is an intrinsic condition for the existence of knowledge, not least because it provides the interpretive support necessary for making sense of its heritage.

More recently Wenger-Trayner et al. (2015) stated that:

Professional occupations, and even more non-professional endeavours, are constituted by a complex landscape of different communities of practice - involved not only in practising the occupation, but also in research, teaching, management, regulation, associations, and many other relevant dimensions.

It can be argued that a community of practice is an innovative knowledge creation system that connects people and ideas, assesses problems, issues and opportunities creatively, creates new opportunities and extends beyond the boundaries of a single organisation.

Communities of practice have differing levels of participation. The core drivers of such communities are convenors, hosts, leaders and active participants. A community is sustained by its core and active members. The beauty of the approach is that members can move in 


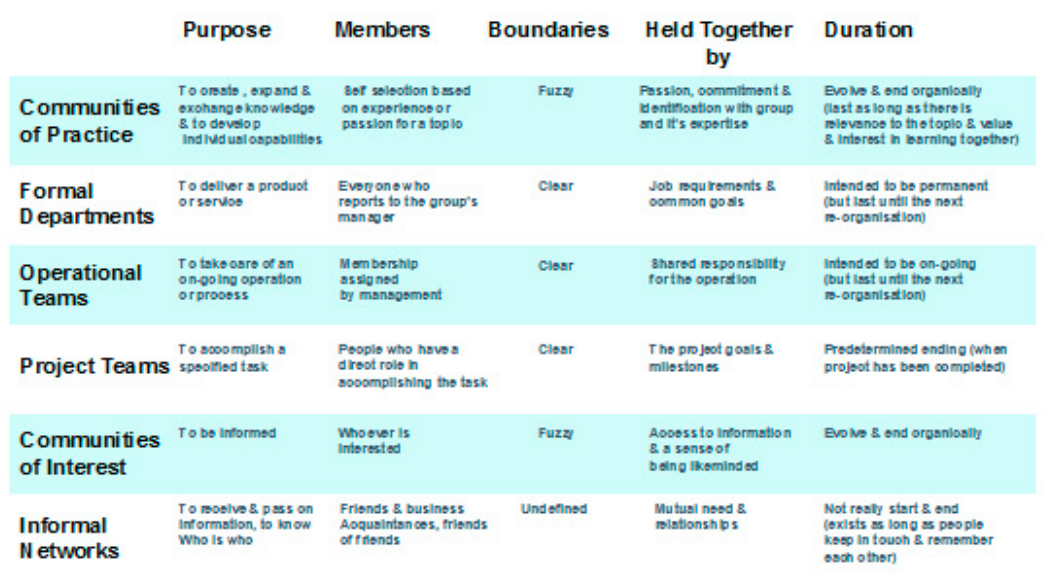

Figure 1. Differences and similarities between informal networks and communities of practice

Source: adapted from: Wenger et al., 2002.

and out, being occasional participants, and peripheral participants are enabled to try out the community and to participate if they find value in its activities. Communities of practice support and enable the creation of knowledge by connecting people who may not otherwise have the opportunities to connect and interact. A community of practice enables sharing through stories, metaphors, and cases, as well as active learning through games and other transformative pedagogical approaches. Members come together to share personal experiences in a way that challenges current thinking and theories, thus enabling the creation of new knowledge. New possibilities are explored, challenges tackled, and mutually beneficial projects initiated. On an individual level, learning is enabled through authentic interactions, coaching, mentoring, and developing members as reflective practitioners (Summer, 2018). An emergent benefit of being a member of a community of practice is exposure to good practices and awareness of what has worked well and what has gone wrong. Open discussions which are enabled through an extraordinary level of trust help members to identify possible solutions and to evaluate good practices. The flow of ideas from an individual to an individual, from a sector to a sector, 
from a discipline to a discipline develops and supports the free flow of ideas, allowing nudges to collide, and in the great coffee house tradition, enables knowledge creation.

Below, the authors present two case studies of communities of practice: one from Poland and one from the United Kingdom.

\section{A CASE STUDY: FREE IN THE CAMP ${ }^{1}$ - THE WORKING GROUP OF THE POLISH SOCIAL GEOGRAPHERS AS AN EXAMPLE OF INFORMAL ACADEMIC COOPERATION DURING THE PERIOD OF REAL SOCIALISM}

Most probably, few people wonder how it was possible that during the period of real socialism the countries located behind "the iron curtain", cut off from global science were nevertheless able to develop science, even in the areas of economic and social sciences, where censorship was particularly strict. One of the methods of coping with such restrictions was voluntary cooperation among scientists.

A case in point is the activities of the Working Group of Polish Social Geographers (Grupa Robocza Polskich Geografów Społecznych, GRPGS) established at the turn of the years 1983 and 1984. The Group's initiator was Dr. Zbigniew Rykiel from the Institute of Geography and Spatial Development at the Polish Academy of Sciences in Warsaw (at present dr hab. prof. of the University of Rzeszów, head of the Urban Sociology and Territorial Communities Unit at the Institute of Sociology, the University of Rzeszów). The Group was being formed in the period soon after a landmark methodological conference held in Radzyń in the summer of 1983. Very important for the future of geographical sciences, the conference was the venue of a unique clash among different research orientations. Discussions were dominated by humanistic and radical trends, which was difficult to accept for academics representing the positivist research approach coexisting with the descriptive and popular trends in classical geography. It should be noted that the positivist approach was highly compatible with Marxist

1 This sarcastic metaphor understandable for people who have the experience of living under real socialism referred to the apparent freedom of the citizens of the countries of so-called "people's democracy", isolated from contacts with the rest of the world, in fact imprisoned as if in a labour camp. 
philosophy and hence enjoyed ideological support in the countries of real socialism as a basis for the concept of planning in science. This issue was described extensively by M. Polanyi (1951) (after: Zmyślony, 2011, p. 152). The conference in Radzyń witnessed not only comprehensive reviews of the research trends dominating in the science of geography in that period but also presentations of individual Polish scientists undertaking research on important social issues. Some of those academics were experimenting with the tools of critical analysis, others were developing the behavioural trend within the positivist approach, and yet others were criticizing positivism from the position of humanistic research orientations. Such approaches were unthinkable in the area of economic geography practised in Poland at that time. Reactions to the discussions held during the conference made young academics aware that in Poland there were many more people perceiving the new approaches as a valid research alternative.

Zbigniew Rykiel invited academics from various universities in Poland to get involved in the undertaking. At the beginning phase there were about a dozen persons associated with the Group, but eventually it had seven permanent active members: from Warsaw - Zbigniew Rykiel from the IGiPZ PAN (The Institute of Geography and Spatial Development at the Polish Academy of Sciences), Hanna Libura ${ }^{2}$ from the University of Warsaw, from Poznan - Ewa Małuszyńska ${ }^{3}$ from the Academy of Economics, and Roman Matykowski ${ }^{4}$ from the Adam Mickiewicz University, from Gdańsk - Iwona Sagan ${ }^{5}$ from the University of Gdańsk, and from Cracow - Bolesław Domański ${ }^{6}$ and Grażyna Prawelska-Skrzypek ${ }^{7}$ (a co-author of this paper) from the Jagiellonian

\footnotetext{
2 After leaving the University of Warsaw, Hanna Libura worked in the banking sector, specializing in project financing. In her career, she reached the position of Director of the Investment Projects Financing Department in BRE Bank Hipoteczny S.A. At present she shares her knowledge and experiences with students at the University of Gdańsk.

3 At present prof. dr hab., Head of the Department of European Studies, the Faculty of International Economy, the University of Economics in Poznań.

4 At present dr hab. prof. of the Adam Mickiewicz University, Head of the Spatial Development Unit, the Institute of Socio-Economic Geography and Spatial Development, the Adam Mickiewicz University.

${ }^{5}$ At present dr hab. prof. of the University of Gdańsk, Head of the Department of Socio-Economic Geography, the Institute of Geography, the University of Gdańsk.

${ }^{6}$ At present prof. dr hab. dean of the Faculty of Geography and Geology at the Jagiellonian University, Head of the Regional Development Unit, the Institute of Geography and Spatial Development.

7 At present prof. dr hab., Head of the Department of Public Management, the Institute of Public Affairs, the Faculty of Management and Social Communication, the Jagiellonian University.
} 
University. The Group never had any political character, although during the first years of its activity (in the period immediately after the lifting of martial law) it was perceived as "politically uncertain". For this reason, some researchers did not want to be associated with it. We had then and still have different political opinions and outlooks on life. But such difference constituted no barrier for our cooperation. We were united by similar research interests and in particular a new approach to research, a belief in science and an ethos-based approach to its understanding and practice.

We decided to meet twice a year to discuss research issues in the field of social geography, especially research conducted from a behavioural perspective and in accordance with the humanistic and (radical) structuralist methodology. The Group was active in the years 1983-1997. We held meetings in our private flats and houses, incurring all related costs of travel, board, and accommodation. We always presented our latest achievements and research plans and discussed appearing methodological doubts and problems. Such discussions were the most time consuming. We presented reports on read scientific literature ${ }^{8}$ and conferences, particularly international ones, that we had managed to attend. Sometimes we prepared articles for scientific journals published in our academic centres. Their topics corresponded to the respective profiles of our interests. A host receiving colleagues in their home was always obliged to prepare a field presentation of a problem selected from the area of social geography and those were extremely interesting study visits focused on particular research problems. A few hours during each study visit lasting usually 2 or 3 days were dedicated to a meeting with an "interesting man". Such meetings gave us the opportunity to meet and talk to outstanding researchers and social activists. Furthermore, we were always able to find some time for participation in important cultural events taking place in cities where our meetings were held. Many friendships were formed among the participants of those meetings. In 2010 after a thirteen years' break

\footnotetext{
8 In those times access to scientific literature was very difficult. It was only the library of the Institute of Geography and Spatial Development at the Polish Academy of Sciences that subscribed to a larger number of foreign academic journals. Hence, we often travelled to that library to read available scientific literature there. Sometimes some of us managed to get a book or a journal from professors from Western countries visiting our universities in Poland. Scientists working for the Polish Academy of Sciences had more opportunities for establishing contacts with abroad. Young scientists from regular universities hardly ever managed to travel abroad and visit Western academic centres.
} 
we resumed the tradition of our regular meetings. Already tenured professors, we met in a slightly smaller group together with our spouses mainly for the purposes of socializing and cultivating our friendships.

This short history of the GRPGS is a good illustration of a life cycle of a community of practice described in terms of so-called agile methodologies and agile teams. Such a community starts with an idea for a new group and a commitment to cooperate; it ends when the community has achieved its objectives or has stopped providing real value to its members. A few years after it had stopped its activities, the GRPGS was revived as a group of friends.

All interviewed members of the GRPGS emphasized the informative value of their informal cooperation and the value of having been confirmed by a group of colleagues with similar scientific interests in their conviction that their research and applied research methods were reasonable. Everybody perceived their cooperation as a factor that had exerted a considerable influence on their professional development. Analysing the history of the Group, its establishment, character and activities, opinions about expectations concerning planned cooperation, one can notice that the Group meets all criteria of a "community of practice" as perceived by S. Herranz et al. (2012) as well as E. Wenger, R. McDermott and W. Snyder (2002). It is also worth referring to P. Summers's opinion that lessons learned by members of a community of practice lead to their development as reflective practitioners, which was also an important trend identified in the course of the conducted research (Summer, 2018).

From the perspective of the objectives of this paper, it was interesting to become familiar with the opinions of researchers participating in various forms of voluntary academic cooperation. Conducted in the form of in-depth interviews, the research comprised five academics, including the two youngest members of GRPGS: Bolesław Domański (BD) and Iwona Sagan (IS), who, at the time of establishing cooperation were young academic teachers in their late twenties. The realities of practising science in the period of real socialism were very much different from those of the contemporary world. Therefore, the interviews were also conducted with other persons who had been or were involved in various forms of voluntary academic cooperation, including communities of practice, including representatives of the younger generation of researchers. In consequence, the interviewees included academics whose professional careers had been spent in a considerable 
part in the period of real socialism (Prof. dr hab. Bolesław Domański, UJ; dr hab. Iwona Sagan, prof. UG; Prof. dr hab. Grażyna Prawelska-Skrzypek, UJ), when the freedom of conducting scientific activities was limited by the political system, as well as those who started to pursue their careers in the democratic system and the free market economy - in the world of open science, in which, simultaneously, market mechanisms permeated science. The co-author of this paper used also her own interpretations and experiences gained before and after the transformation of the political and economic systems. Besides the persons mentioned above, my interviewees were Monika Kostera, ${ }^{9}$ Wojciech Czakon ${ }^{10}$ and Beata Jałocha. ${ }^{11}$

All interviewees are continually active in various forms of voluntary academic cooperation. Their opinions on the causes of their involvement in informal academic cooperation, the features determining its attractiveness, as well as its effects and advantages are presented in Table 1.

\title{
A CASE STUDY: IMPROVEMENT COMMUNITY OF PRACTICE
}

\begin{abstract}
"Making a difference, making it happen, sharing experiences". This case study is based on the theoretical framework presented in Table 2.
\end{abstract}

9 Monika Kostera is professor of management sciences in the field of economic and humanistic sciences at the Faculty of Management and Social Communication at the Jagiellonian University and professor at the Linnaeus University in Sweden. She was also professor at Durham University in the United Kingdom. For many years she has been known as a person organizing cooperation among many researchers, particularly young ones, selflessly sharing her knowledge and experiences with others, supporting numerous research and didactic initiatives. She has also gained extensive experience related to her functioning in the international research group CMS.

10 Wojciech Czakon is professor of management sciences in the field of economic sciences, Head of the Department of Strategic Management, the Institute of Economics, Finance and Management at the Jagiellonian University. He was earlier associated with the University of Economics in Katowice. He is one of the co-founders of "Kontrapunkty", an informal network undertaking in the form of a community of practice gathering researchers specializing in management sciences from the University of Warsaw and the Jagiellonian University. He is also an active member of the international network of researchers CENA.

11 Beata Jałocha holds a doctoral degree in management sciences. She is a young researcher working for the Institute of Public Affairs at the Jagiellonian University. She initiates and participates in various forms of informal, domestic and international academic cooperation. She also shares her knowledge effectively with her colleagues from her Institute. 
Table 1. Voluntary academic cooperation in the opinions of the surveyed researchers

\begin{tabular}{|c|c|}
\hline $\begin{array}{l}\text { Aspects of voluntary } \\
\text { academic cooperation }\end{array}$ & Opinions of surveyed academics \\
\hline $\begin{array}{l}\text { Reasons for getting } \\
\text { involved in various forms } \\
\text { of voluntary academic } \\
\text { cooperation }\end{array}$ & $\begin{array}{l}\text { A sense of a community of research interests and a wish to } \\
\text { deepen them } \\
\text { A similar approach to the understanding of science and its } \\
\text { practice } \\
\text { A need for demanding, in-depth, open scientific discussions } \\
\text { and intellectual conversations }\end{array}$ \\
\hline Dominant features & $\begin{array}{l}\text { The openness of scientific discussions } \\
\text { The sharing of knowledge and experiences } \\
\text { The provision of critical and constructive feedback on } \\
\text { research conducted by cooperation participants }\end{array}$ \\
\hline $\begin{array}{l}\text { The social aspects of vol- } \\
\text { untary cooperation }\end{array}$ & $\begin{array}{c}\text { Friendly relations } \\
\text { Mutual kindliness } \\
\text { Mutual friendliness } \\
\text { in cooperation. } \\
\text { Mutual trust strengthened in parallel to progress } \\
\text { The building of relations within an interdisciplinary and } \\
\text { multipardigmatic academic community } \\
\text { The development of the ethos-based approach to the practice } \\
\text { of science and cooperation }\end{array}$ \\
\hline $\begin{array}{l}\text { Individual advantages } \\
\text { achieved thanks to volun- } \\
\text { tary cooperation }\end{array}$ & $\begin{array}{c}\text { The sharing of information, thoughts, and ideas } \\
\text { The expansion of knowledge } \\
\text { Making sure that intended research directions or methods } \\
\text { are reasonable and correct } \\
\text { The acquisition of academic and intellectual self-confidence } \\
\text { and courage } \\
\text { The improvement of skills - mainly those related to critical } \\
\text { thinking and academic discussions } \\
\text { Researchers' passion for science becomes a pleasure for } \\
\text { them, thus unblocking and stimulating academic creativity }\end{array}$ \\
\hline $\begin{array}{l}\text { Institutional effects and } \\
\text { advantages achieved } \\
\text { thanks to employees' } \\
\text { involvement in voluntary } \\
\text { academic cooperation }\end{array}$ & $\begin{array}{l}\text { The development of science and didactics within a universi- } \\
\text { ty - all interviewees were involved in innovative research, } \\
\text { had courage to apply new research approaches, in their } \\
\text { respective universities developed and implemented new } \\
\text { curricula and courses, developed and implemented perma- } \\
\text { nent organizational changes } \\
\text { Contributing to the improvement of a university's position } \\
\text { by initiating and participating in communities of practice }\end{array}$ \\
\hline $\begin{array}{l}\text { Effects for the develop- } \\
\text { ment of science resulting } \\
\text { from voluntary academic } \\
\text { cooperation }\end{array}$ & $\begin{array}{c}\text { Creating an environment/place for the forging of new ideas, } \\
\text { the progress and development of science - an environ- } \\
\text { ment favourable for the occurrence of the synergy effect } \\
\text { and creativity } \\
\text { The development of tacit knowledge; the appearance of new } \\
\text { ideas, the development of science } \\
\text { An antidote to the bureaucratization of science that kills } \\
\text { researchers' creativity } \\
\text { The development of emancipatory attitudes and a sense of } \\
\text { academic autonomy }\end{array}$ \\
\hline $\begin{array}{l}\text { Effects for the academic } \\
\text { community }\end{array}$ & $\begin{array}{c}\text { The deepening of the community's trust based on high } \\
\text { ethical standards } \\
\text { The building and strengthening of interdisciplinary relations } \\
\text { The building of a community of knowledge }\end{array}$ \\
\hline
\end{tabular}

Source: the authors' own work. 


\section{"MAKING A DIFFERENCE, MAKING IT HAPPEN, SHARING EXPERIENCES" - FORMATION OF A COMMUNITY OF PRACTICE}

In 2008 , a chance encounter between a member of staff of Portsmouth

Table 2. Framework for analysis

\begin{tabular}{|c|c|c|}
\hline $\begin{array}{l}\text { History - time lines of cooper- } \\
\text { ation Beginnings - initial and } \\
\text { continuity }\end{array}$ & $\begin{array}{l}\text { SIPOC - suppliers, inputs, } \\
\text { process, outputs and } \\
\text { customers }\end{array}$ & $\begin{array}{c}\text { Value proposition - pur- } \\
\text { pose of these co-operations. } \\
\text { Why? What? How? When? } \\
\text { Who? }\end{array}$ \\
\hline Network organisations & Core activities & \\
\hline $\begin{array}{c}\text { Costs - what we give? } \\
\text { Finance, energy, expertise, } \\
\text { hosting meetings, materials } \\
\text { University perspective }\end{array}$ & $\begin{array}{l}\text { Benefits - how are these } \\
\text { evaluated? REF, TEF, } \\
\text { collaborations, knowledge } \\
\text { exchange, to the university }\end{array}$ & $\begin{array}{c}\text { Contribution to expertise } \\
\text { and capability in research } \\
\text { and practice }\end{array}$ \\
\hline
\end{tabular}

Source: the authors' own work.

Business School and the then leader of the P21 team of process improvers in HM Dockyard Portsmouth led to the establishment of a Community of Practice $(\mathrm{CoP})$ of improvement and change-agent professionals. The aims of this community were to promote recognised improvement tools and techniques to improvement facilitators based in a range of organisations, and provide opportunities to discuss and reflect upon tools and techniques, and share ideas on good practice. From 2009 to 2018, the CoP has grown a core membership of more than 50 individuals, drawn from a range of organisations, including private sector companies (insurance, defence, consultancy), governmental organisations, public sector organisations; and education establishments (including academic, technical and professional staffs). Proceedings are conducted under the Chatham House Rule (Chatham House, 2014). The forum enables members to explore and deconstruct tools and techniques in order to use them in their own organisations, but also to develop the "discipline" of improvement and change management theory. The resulting $\mathrm{CoP}$ enabled members to collaborate across organisations/ sectors in order to develop and share knowledge. The contribution to expertise and capability is to create a community of inquiry to advance the understanding, theory and development of improvement tools and techniques and their application in organisational processes. 
The disciplines explored have developed over the years to encompass lean, six sigma, systems thinking, visual management, sustaining and leading change. Members are encouraged to help form the yearly themes at the yearly celebration event.

Some introductory workshops during 2008/9 discussed systems thinking and systems methods. The positive feedback and experiences of the workshop leaders and participants prompted further workshops, addressing areas such as value stream mapping and related visualisation techniques. A further programme in 2010/11 focused on issues highlighted by members regarding management of change and

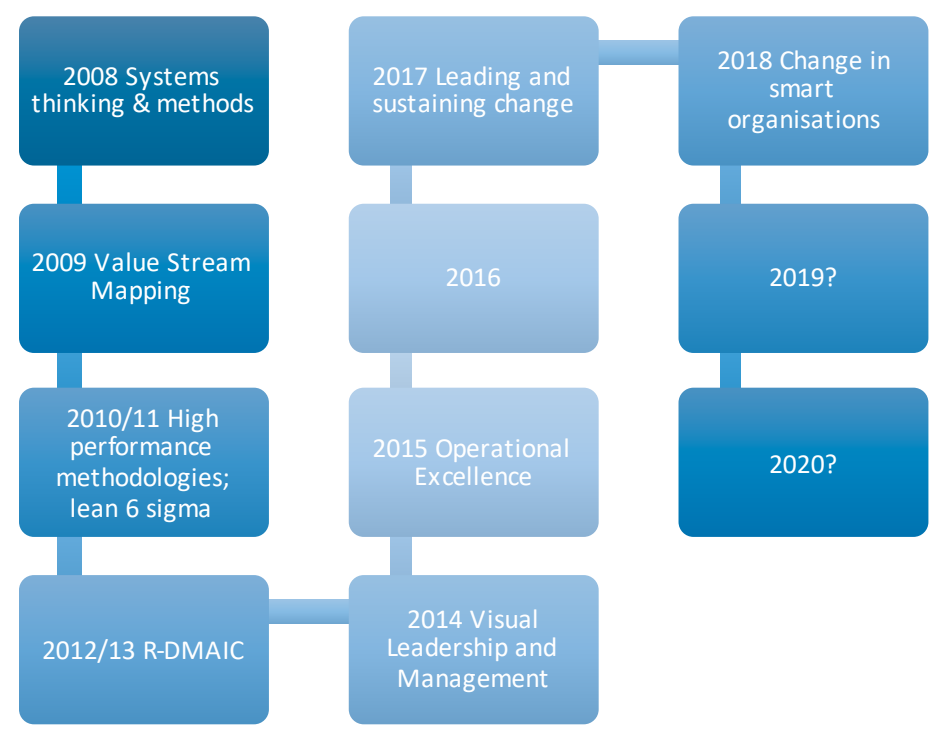

Figure 2. Time line of Improvement Community of Practice

Source: the authors' own work.

high performance methodologies (such as Lean / six sigma). Policy deployment / Hoshin Kanri and visual leadership techniques such as mind mapping and rich picture visioning were also incorporated. At the end of each cycle of workshops, the co-chairs request topics of interest from the community and produce a programme to meet those needs. During 2012/13, members considered the RDMAIC cycle (a Six Sigma "roadmap" for process improvement), each member applying their learning to a specific project in the context of their own practice. 
Typically, the workshops are of half-day duration, beginning with some formal input on techniques, followed by case exercises and group discussions. In 2014, the community embarked on a programme considering visual management approaches. A3 sheets, summarising elements of tools and techniques, are prepared and used to guide participants and provide an on-going resource library, distributed via a cloud sharing service. Subsequent themes included visual leadership, Operational Excellence, Leading and sustaining change and currently we are focusing on change in smart organisations.

\section{THE COMMUNITY AS A VEHICLE FOR RESEARCH: CONTRIBUTIONS TO THE RESEARCH EXCELLENCE FRAMEWORK AND KNOWLEDGE EXCELLENCE FRAMEWORK}

All organizational knowledge is inherently contextual, and embedded within individuals and groups who are active within a particular organization. Argyris (1993) points out that there can be a significant gap between learning something worth knowing and being able to act upon this new understanding in context. When we are immersed in the dynamic, messy contexts of everyday working life, we must draw upon combinations of propositional, procedural and tacit (embedded) knowledge that are actionable in context. Within a dynamic context, that will mean creating new knowledge on a continual basis through individual and group sense-making and reflection processes. Van de Ven (2007) highlights a perceived gap between practice and theory building about practice, which inevitably arises when research takes place in a closed system of academic interest. Multiple perspectives contributed by stakeholders from differing backgrounds are needed to encourage sufficient attention to the demands of rigour and of relevance in deepening understandings of complex problems. This "engaged scholarship", in which scholars interact with other stakeholders, such as "users", practitioners, sponsors and clients, develops participative forms of inquiry.

In the past, most of the research conducted in the field of operations management, improvement and change was based on statistical survey analysis and mathematical modelling. However "embracing a field investigation technique such as case studies is bound to make 
the individual researcher, and the field in general richer and better prepared to solve real problems" (McCutcheon \& Meredith, 1993, p. 217). Van de Ven argues that knowledge transfer, as opposed to one-way communication of findings, requires conversation, sense making and collaboration between producers and users of research knowledge (Van de Ven, 2007, p. 246). He goes on to define as collaborative engaged scholarship: "Collaborative research teams are often composed of insiders and outsiders who jointly share the activities listed ... in order to co-produce basic knowledge about a complex problem or phenomenon" (2007, p. 27).

Schon (1987) discussed the idea of a reflective practicum within business schools, to bridge the worlds of scholarship and practice. This, he suggested, must: "cultivate activities that connect the knowing and reflection-in-action of competent practitioners to the theories and techniques taught as professional knowledge in academic courses" (Schon, 1987, p. 312). It was reflection upon issues such as these that gave the initiators of the community of practice "making a difference, making it happen" the foundation for the project described here.

As such, the concept of a community of practice helps to focus on the duality of tacit and explicit "knowing" inherent in the exercise of any professional expertise. Bruner (1996) points out that people do not just learn about the world, they also learn to be. It is learning to behave in "socially recognized ways" that can only be achieved through legitimate peripheral participation. Communities are constituted in many ways, some formal and some informal. Much work in the field of knowledge management has derived from study of such communities, e.g. Seely Brown's study of tacit knowledge sharing among photocopier engineers at Xerox (Brown \& Duguid, 1991). Over time, it has been recognised that it is possible to use communities as a vehicle for co-creation and sharing of new knowledge, and attempted to cultivate them within organisations for this purpose (Wenger et al., 2002).

In consideration of all of these issues, the founders believed that the community formed, though possibly transient in scope and crossing the boundaries of a number of culturally disparate organizations, could form the basis of a useful reflective practicum. Although not a community in the strict sense intended by Lave and Wenger, the invited membership had potential to create ideas through opportunities to explore aspects of practice together. Through collective exploration and reflective discussion of aspects of their own professional practice, 
together with input of theoretical models from academic members, the community could generate new and valuable professional knowledge which might "leak" into their own organizational worlds.

From its inception, the founders of the $\mathrm{CoP}$ considered its potential, not just to promote effectiveness among improvement professionals through use of good practice, but to go beyond this to generate new and improved understandings of the field. The intention was to avoid passive, one-way communication and to embrace Van de Ven's suggestion of "conversation, sense-making and collaboration between producers and users of research knowledge" (2007, p. 246) in a Community of Inquiry (Peirce, 1955), in order to create and share new knowledge. Clearly, there is perceived value in the activities of the Community for its members. From the collective reflection sessions, it has become clear that value can be derived in three ways: first, from the formal input that introduces tools and techniques not previously considered; second, from networking with other engaged professionals to discuss issues of common interest under Chatham House rules; and thirdly, transcending these two, from insights gained into use of the various techniques through feedback in plenary sessions. This latter category clearly indicates scope for a more formal research lens. It appears that reflection is the key.

\section{REFLECTION FOR PRACTICE, THEORY AND THE DEVELOPMENT OF COMMUNITIES OF PRACTICE}

The following comments from the community of practice members provide a rich insight into the "why" scholars and practitioners get involved. The responses have been clustered around themes.

\section{CONCLUSION}

The conducted research shows that the rationalities of the communities of researchers are based on mechanisms other than political or economic systems. What can be found in them is interpersonal principles based on collective and solidaristic forms of social interactions: cultural reproduction, social integration, and member socialization (Habermas, 1987). 
Table 3. Benefits and values for members of CoP Improvement Community of Practice

\begin{tabular}{|c|c|}
\hline $\begin{array}{l}\text { Group cohesiveness } \\
\text { through dialogue }\end{array}$ & $\begin{array}{l}\text { The social dimension of the community has been recognised to be } \\
\text { important from the beginning. Many opportunities for networking } \\
\text { and free discussion are supported, including an active LinkedIn } \\
\text { and Facebook Group. Critical stance has been encouraged and } \\
\text { a collegial atmosphere has been developed and supported. }\end{array}$ \\
\hline $\begin{array}{l}\text { Primacy of activity } \\
\text { and reflection }\end{array}$ & $\begin{array}{l}\text { Workshops include collaborative working around example case } \\
\text { studies in order to promote dialogue. Participants have not just } \\
\text { "listened" to exposition of techniques but have used them. Many } \\
\text { have taken particular tools back into their own workplace and } \\
\text { have subsequently volunteered feedback on their experiences, in- } \\
\text { cluding examples where new combinations of tools and techniques } \\
\text { have been trialled. }\end{array}$ \\
\hline Openness of debate & $\begin{array}{l}\text { Participants have been encouraged to air criticisms of the various } \\
\text { techniques and their use and all workshops have included sessions } \\
\text { in which usefulness is examined. Every session has ended with } \\
\text { evaluation in plenary. }\end{array}$ \\
\hline $\begin{array}{l}\text { Surfacing of as- } \\
\text { sumptions, general- } \\
\text { izations, examples }\end{array}$ & $\begin{array}{l}\text { Dialogue is supported in small group work and in plenary in order } \\
\text { to draw lessons from activity. Participants are encouraged to } \\
\text { bring their stories to the community during annual "Celebration" } \\
\text { events. }\end{array}$ \\
\hline $\begin{array}{l}\text { Collaboration in } \\
\text { co-operative rea- } \\
\text { soning }\end{array}$ & $\begin{array}{l}\text { Discussion supports surfacing of types of reasoning; criteria for } \\
\text { evaluation; conceptual modelling; examination of rule building } \\
\text { and extrapolation of principles. }\end{array}$ \\
\hline $\begin{array}{l}\text { Increasing sensitiv- } \\
\text { ity to meaningful } \\
\text { nuance of contextual } \\
\text { differences }\end{array}$ & $\begin{array}{l}\text { Dialogue helps to surface differences in practice between the vari- } \\
\text { ous organizational contexts represented in the community. In this } \\
\text { way, it is possible to debate the usefulness of techniques and to } \\
\text { evaluate variations in order to consider whether contextual differ- } \\
\text { ences yield any ideas of "best practice" or generalizable lessons. }\end{array}$ \\
\hline $\begin{array}{l}\text { Seeking after under- } \\
\text { standings through } \\
\text { group sense-making } \\
\quad \& \text { dialogue }\end{array}$ & $\begin{array}{l}\text { Through all of the above, in dialogue and critical debate, the com- } \\
\text { munity attempts to support enhancement of professional practice } \\
\text { in process improvement. Whether it is possible to go beyond this } \\
\text { and capture understandings that might be disseminated as re- } \\
\text { search findings remains to be explored. }\end{array}$ \\
\hline
\end{tabular}

Source: the authors' own work.

The communities of practice described above show that they are united by the common idea of cooperation among people who share their passions and desires for solving important problems and/or who create and share knowledge in a common discipline. However, among communities there are significant differences concerning the understanding of the role of science and the methods of practising science. The communities identified in the Polish academic world are oriented more towards improving their research toolkits, play a formative role important for the shaping of academic attitudes within the meaning of the development of the academic ethos. Polish solutions illustrate 
the understanding of scientific excellence directed towards the inside and the development of science as an autotelic value, as well as the understanding of faithfulness to science. In the British system, where great emphasis is placed on the impact of science and universities on society at large and where such impact is a very important dimension of scientific excellence, communities of practice go beyond universities and focus on cooperation between research theoreticians and research practitioners who implement scientific achievements and gain practical experience outside universities. In Poland, science has a more general meaning, while in Britain, it is understood in a more interactive approach combining science with social and economic life.

It also results from changes in the approach to innovation. The contemporary approach focuses on cooperation networks and the synergy of various communities where new ideas are created and verified. Such networks, including communities of practice, are attractive insofar as they provide certain values to both researchers and other parties participating in such cooperation (entrepreneurs, representatives of various institutions, society). They will be attractive as long as they continue to provide values.

It should be kept in mind that communities of practice have a certain life cycle. Being informal and based on good will and trust, they last as long as they are able to provide values. Unless they change their way of functioning, e.g. by institutionalization, during the final stages of the life cycle they can transform into other forms such as social meetings of colleagues and friends because previously established relations become more permanent, based on trust and ethics.

\section{REFERENCES}

Argyris, C. (1993). Knowledge for Action: A Guide to Overcoming Barriers to Organizational Change. San Francisco: Jossey-Bass Inc. Publishers.

Brown, J. S. \& Duguid, P. (1991). Organizational learning and communities-of-practice: Toward a unified view of working, learning, and innovation. Organization Science, 2(1), 40-57.

Bruner, J. S. (1996). The Culture of Education. Cambridge (Mass.): Harvard University Press.

Chatham House (2014). The Chatham House Rule, http://www.chathamhouse.org/ about-us/chathamhouserule (accessed: $15^{\text {th }}$ December 2019). 
Collini, S. (2012). What Are Universities for? London: Penguin.

Evans, J., Jones, R., Karvonen, A., Millard, L. \& Wendler, J. (2015). Living labs and co-production: University campuses as platforms for sustainability science. Current Opinion in Environmental Sustainability, 16, 1-6.

Geppert, M. \& Hollinshead, G. (2017). Signs of dystopia and demoralization in global academia: Reflections on the precarious and destructive effects of the colonization of the Lebenswelt. Critical Perspectives on International Business, 13(2), 136-150.

Graczyk, P. (2015). Embedding a Living Lab Approach at the University of Edinburgh. Edingurgh: University of Edinburgh, https://www.ed.ac.uk/files/atoms/files/ embedding_a_living_lab_approach_at_the_university_of_edinburgh.pdf (accessed: $15^{\text {th }}$ December 2019).

Habermas, J. (1987). The Theory of Communicative Action. Vol. 2: Lifeworld and System. Trans. T. McCarthy. Boston: Beacon Press.

Herranz, S., Díez, D., Díaz, P. \& Hiltz, S. R. (2012). Exploring the design of technological platforms for virtual communities of practice. In: Information Systems for Crisis Response and Management Conference (ISCRAM).

Lave, J. \& Wenger, E. (1991). Situated Learning. Legitimate Peripheral Participation. Cambridge: University of Cambridge Press.

McCutcheon, D. M. \& Meredith, J. R. (1993). Conducting case study research in operations management. Journal of Operations Management, 11(3), 239-256.

Nonaka, I. (1991). Models of Knowledge Management in the West and Japan. Vol. 91-99. Stockholm: Stockholm School of Economics, Institute of International Business.

Peirce, C. S. (1955). The principles of phenomenology. In: J. Buchler (ed.), Philosophical Writings of Peirce (pp. 74-97). New York: Dover Publications.

Schon, D. A. (1987). Educating the Reflective Practitioner. San Francisco: Jossey-Bass Publishers.

Summer, P. (2018). The Reflective Project Management Practitioner. University of Winchester, $\mathrm{PhD}$ thesis.

Van de Ven, A. H. (2007). Engaged Scholarship: A Guide for Organizational and Social Research. Oxford: Oxford University Press on Demand.

Wenger, E. (1999). Communities of Practice: Learning, Meaning, and Identity. Cambridge: Cambridge University Press.

Wenger, E., McDermott, R. A. \& Snyder, W. (2002). Cultivating Communities of Practice: A Guide to Managing Knowledge. Boston (Mass.): Harvard Business School Press. 
Wenger-Trayner, E. \& Wenger-Trayner, B. (2015). Introduction to Communities of Practice: A Brief Overview of the Concept and Its Uses. Grass Valley, CA: Wenger-Trayner.

Zmyślony, I. (2011). Geneza koncepcji nauki Michaela Polanyi'ego - obrona autonomii nauki. Zagadnienia Naukoznawstwa, 47(2/188), 145-165.

\title{
WSPÓLNOTA PRAKTYKI JAKO FORMA DOBROWOLNEJ WSPÓKPRACY AKADEMICKIEJ
}

\begin{abstract}
Abstrakt
Wyzwania współczesności stymuluja poszukiwania form aktywności akademickiej pobudzających procesy twórcze, wyzwalających kreatywność oraz wspierających współpracę uczelni z otoczeniem społeczno-gospodarczym, w tym współtworzenie w nich wiedzy przy aktywnym udziale otoczenia. Takie efekty przynosi współpraca w ramach wspólnoty praktyków (community of practice) - będacej tradycyjna, a zarazem ponownie odkrywaną forma samoorganizacji środowiska akademickiego.

Autorzy przedstawiaja w artykule przykłady nieformalnej współpracy akademickiej w Polsce i Wielkiej Brytanii, bazując na analizie danych zastanych oraz opiniach osób uczestniczacych w tego typu formach współpracy.

Pokazując niezwykłą efektywność takiego sposobu pracy, jego wpływ na stymulację procesów twórczych, rozwój indywidualny, korzyści instytucjonalne, podkreślając jego kluczowe zalety - brak formalizacji i radość tworzenia oraz dostrzegając potencjalne zagrożenia, autorki mają nadzieję pobudzić szerszą dyskusję nad renesansem tradycyjnych form pracy akademickiej, adekwatnych dla akademickiego stylu pracy i życia.
\end{abstract}

Słowa kluczowe: nieformalna współpraca akademicka, wspólnoty praktyków 